\title{
OCT4 expression regulated apoptosis and cell cycle in myeloma cells
}

\author{
Sorush Niknamian
}

This manuscript has been withdrawn by bioRxiv because the author provided false information about his affiliation. 